\title{
Selvmordsforebygging blant ungdom i Nordland
}

\author{
Ved A nne Line Diesen og Pia Birgitte Jessen
}

Siden 1997 har Nordland fylke hatt et selumordsforebyggende prosjekt med prosjektleder i $50 \%$ stilling første år, deretter $75 \%$ stilling. Prosjektet ble vedtatt i fylkesutvalget etter et innlegg fra sykehusprest Gunnar Kristiansen på Nordland psykiatriske sykehus (NPS). Bakgrunnen for vedtaket var flere selumordsforsøk og selumordstanker blant ungdom.

\section{Målgruppe}

$M$ ål gruppa for prosjektet var i utgangspunktet elever i videregåen de skole, men prosjektet har endret seg til å omfatte den yngre del av befolkningen. Selvmordsraten blant unge menn fra 20 - 29 år har tidligere vært høyere i N ord-N orge enn i resten av landet, og prosjektet ønsket også å favne denne gruppa. Derfor er det inngått et samarbeid med Forsvaret i Bodø.

\section{Målsetting}

1. Ø ke kunnskap om selvmord og selvmordsforebyggende arbeid blant skoleog helsepersonell i hele fylket.

2. Styrke skole- og helsepersonels muligheter til à identifisere el ever i faresonen, samt utvikle rutiner og samarbeid som sikrer at elever får den hjelp de trenger.

3. Bedre elevenes evne til å mestre problemer og livskriser. Tilbud om kurs/fagdag til alle skoler.

A lle ansatte i videregående skoler og deres samarbeidspartnere har fătt tilbud om en undervisningsdag med forebygging av selvmord som tema, og med ett unntak har de takket ja.

\section{Tverretatlige ressursgrupper}

Prosjektet ble tidlig presentert for alle rektorer i fylket, og vi møtte stor velvilje på en besøksrunde ved oppstart. Representanter fra skolene, kommuner, barne, ungdoms- og voksen psykiatrien, pedagogisk-psykologisk tjeneste, politiet, Kirken, utekontakten og andre som var spesi elt engasjert i lokalt forebyggende arbeid, møtte opp. For å sikre elevmedvirkning i prosjektet inviterte vi også elevrepresentanter til disse møtene. Vi dannet 11 tverrfaglige ressursgrupper i hele fylket, som har blitt sentrale i det videre arbeidet. $\mathrm{Vi}$ har hatt to felles samlinger for alle ressursgruppene. G ruppene har hatt besøk fra Senter for selvmordsforebygging i N ord-N orge, og siste prosjektår har alle gruppene fâtt tilbud om kurset Intervensjon ved selvmordsfare fra Living W orks.

\section{Elevmedvirkning}

Det var en forutsetning at det skulle være elever med i ressursgruppene, slik at el evenes bidrag om egen hverdag kunne komme tydelig fram. G ruppene har brukt mye tid på å finne fram til gode metoder for å inkludere el evrepresentantene. Prosjektet har samarbeidet med elevombudet og elevorganisasjonene, og i løpet av våren 2000 skal vi ha vår tredje temasamling. Temaet skal være "Ung, stolt og homofil". Det er valgt på bakgrunn av N OVA rapporten $\mathrm{nr}$. 1/99 som viste at homofile og lesbiske oftere har selvmordstanker og oftere gjør sel vmordsforsøk enn den øvrige befolkningen. Disse er også en gruppe som $\mathrm{H}$ elsetilsynet ønsker å fokusere på i $\mathrm{H}$ andlingsplan mot selvmord.

\section{Psykiatrien og}

selvmordsforebyggende arbeid

O pptrappingsplan for psykisk helse 1999 - 2006 legger vekt på at psykiatritjenestene skal bli mer tilgjengelig og bidra aktivt i tverretatlig samarbeid og forebyggende arbeid. Selvmordsforebyggende arbeid vil være en naturlig del av virksomheten. Det er foreslått å videreføre prosjektet innen en egen utviklingsavdeling som er under planlegging på N PS, der kompetanseheving til ressursgruppene kan videreutvikles i samarbeid med distriktspsykiatriske sentre. Prosjektet er ikke en del av handlingsplanen, og skal evalueres av N ordlandsforskning i år 2000.

\section{Ressursgruppe i Vesterålen}

I Vesterålen ble det i oktober 1997 etablert en ressursgruppe for å forebygge selvmord i den videregående skolen. G ruppen består av rådgivere fra de fleste videregående skoler, to helsesøstre, to fra pedagogisk-psykologisk distriktssenter (PPD), en fra oppfølgingstjenesten, to elever, en fra barne- og ungdomspsykiatrisk poliklinikk (BU P) og en fra voksenpsykiatrisk poliklinikk (leder for gruppen). G ruppen har jevnlige møter. Det har bl. a. blitt utarbeidet en handlingsplan for gruppen, og det har vært jobbet med kriseplaner for skolene.
Flere fra V esterålen har deltatt på samlinger for ressursgruppene som har vært arrangert av prosjektet. G ruppemedlemmene har uttrykt ønske om opplæring og øking av kunnskap omkring selvmordsforebyggende arbeid. På bakgrunn av det har Bjørnar U rke fra BU P og Pia Birgitte Jessen hatt undervisning for gruppen. Fjorten personer har deltatt i kurs i intervensjon ved selvmordsfare, som ble meget positivt mottatt. D et har også vært arrangert en halvdagssamling med lederne fra Senter for forebygging av selvmord i N ordN orge.

D et er ønske om videre samarbeid med spesialisthel setjen esten omkring det selvmordsforebyggende arbeidet. Poliklinikkene i Vesterålen jobber mye med kompetanseheving blant samarbeidspartnere. D ette er en del av det daglige arbeidet, og det selvmordsforebyggende arbeidet er et prioritert område.
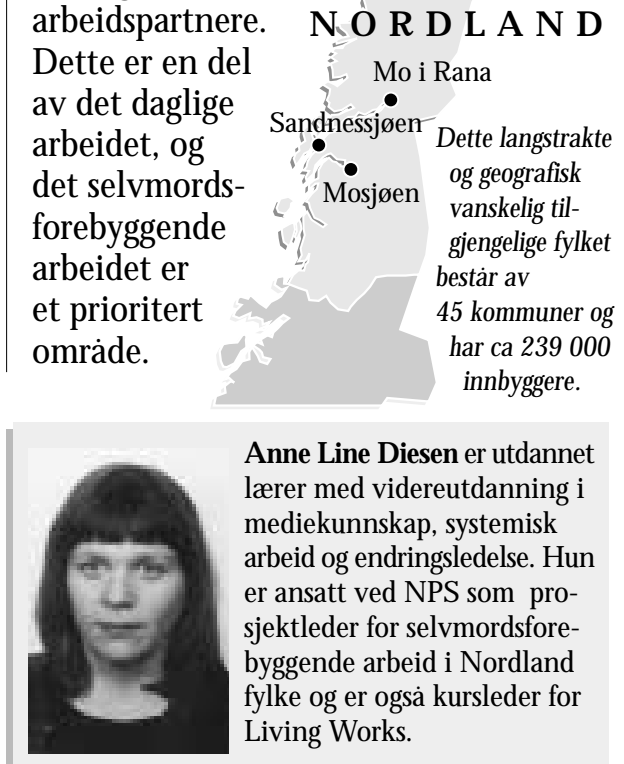

A nne Line D iesen er utdannet Iærer med videreutdanning i mediekunnskap, systemisk arbeid og endringsl edelse. H un er ansatt ved N PS som prosjektleder for selvmordsforebyggende arbeid i $\mathrm{N}$ ordland fylke og er også kursleder for Living W orks.

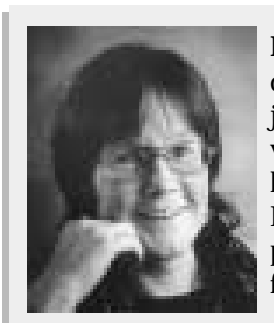

Pia Birgitte Jessen er utdannet ergoterapeut. H un jobber som utviklingsleder ved Voksen psykiatrisk poliklinikk, Stokmarknes sykehus. $\mathrm{H}$ un er leder for ressursgruppen i Vesterålen og er trener for Living W orks. 